\title{
Operation Everest III: energy and water balance
}

Citation for published version (APA):

Westerterp, K. R., Meijer, E. P., Rubbens, M., Robach, P., \& Richalet, J. P. (2000). Operation Everest III: energy and water balance. Pflugers Archiv-European Journal of Physiology, 439(4), 483-488. https://doi.org/10.1007/s004240050967

Document status and date:

Published: 01/01/2000

DOI:

10.1007/s004240050967

Document Version:

Publisher's PDF, also known as Version of record

Document license:

Taverne

Please check the document version of this publication:

- A submitted manuscript is the version of the article upon submission and before peer-review. There can be important differences between the submitted version and the official published version of record.

People interested in the research are advised to contact the author for the final version of the publication, or visit the DOI to the publisher's website.

- The final author version and the galley proof are versions of the publication after peer review.

- The final published version features the final layout of the paper including the volume, issue and page numbers.

Link to publication

\footnotetext{
General rights rights.

- You may freely distribute the URL identifying the publication in the public portal. please follow below link for the End User Agreement:

www.umlib.nl/taverne-license

Take down policy

If you believe that this document breaches copyright please contact us at:

repository@maastrichtuniversity.nl

providing details and we will investigate your claim.
}

Copyright and moral rights for the publications made accessible in the public portal are retained by the authors and/or other copyright owners and it is a condition of accessing publications that users recognise and abide by the legal requirements associated with these

- Users may download and print one copy of any publication from the public portal for the purpose of private study or research.

- You may not further distribute the material or use it for any profit-making activity or commercial gain

If the publication is distributed under the terms of Article $25 \mathrm{fa}$ of the Dutch Copyright Act, indicated by the "Taverne" license above, 


\section{K.R. Westerterp · E.P. Meijer • M. Rubbens \\ P. Robach $\cdot$ J-P. Richalet \\ Operation Everest III: energy and water balance}

Received: 17 May 1999 / Received after revision: 20 September 1999 / Accepted: 28 October 1999 / Published online: 18 November 1999

\begin{abstract}
We hypothesized that hypoxia decreases energy intake and increases total energy requirement and, additionally, that decreased barometric pressure increases total water requirement. Energy and water balance was studied over 31 days in a hypobaric chamber at 452-253 Torr (corresponding to 4,500-8,848 m altitude), after 7 days acclimatization at $4,350 \mathrm{~m}$. Subjects were eight men, age $27 \pm 4$ years (mean \pm SD), body mass index $22.9 \pm 1.5 \mathrm{~kg} / \mathrm{m}^{2}$. Food and water intake was measured with weighed dietary records, energy expenditure and water loss with labelled water. Insensible water loss was calculated as total water loss minus urinary and faecal water loss. Energy intake at normoxia was $13.6 \pm 1.8 \mathrm{MJ} / \mathrm{d}$. Energy intake decreased from $10.4 \pm 2.1$ to $8.3 \pm 1.9 \mathrm{MJ} / \mathrm{d}(P<0.001)$ and energy expenditure from $13.3 \pm 1.6$ to $12.1 \pm 1.8 \mathrm{MJ} / \mathrm{d}$ $(P<0.001)$ over the first and second 15-day intervals of progressive hypoxia. Absolute insensible water loss did not change $(1.67 \pm 0.26$ and $1.66 \pm 0.37 \mathrm{l} / \mathrm{d})$, however, adjusted for energy expenditure it increased with ambient pressure reduction $(P<0.05)$. In conclusion, hypoxia induced a negative energy balance, mainly by a reduction of energy intake. Overall insensible water loss was unchanged because the increase in respiratory evaporative water loss was counterbalanced by a decrease in metabolic rate that probably limited the hypoxia-induced increase in ventilation.
\end{abstract}

Key words Energy intake $\cdot$ Water intake $\cdot$ Energy expenditure $\cdot$ Water loss $\cdot$ Body composition

K.R. Westerterp ( $\bullet$ ) E.P. Meijer · M. Rubbens Department of Human Biology, Maastricht University, P.O. Box 616, NL-6200 MD Maastricht, The Netherlands e-mail: k.westerterp@hb.unimaas.nl

Tel.: +31-43-3881628, Fax: +31-43-3670976

P. Robach $\cdot$ J-P. Richalet

Association pour la Recherche en Physiologie

de l'Environnement, France

\section{Introduction}

An important problem during chronic exposure to high altitude is the maintenance of energy and water balance. Many studies have shown that subjects lose significant amounts of weight, depending on the altitude reached and the time spent there $[1,6,7,8,13,15,16,19,20]$. However, weight loss can be largely prevented in the presence of sufficient comfort as shown at an altitude of $4,300 \mathrm{~m}[2,3]$ and even at 5,050 $\mathrm{m}$ by supplying the subjects with highly palatable diets [10]. A negative energy balance at high altitude is mainly the result of malnutrition. Energy expenditure, as measured with doubly labelled water, does not reach exceptionally high levels $[19,20]$ and the absorption of energy seems to be affected only marginally at altitudes up to $6,542 \mathrm{~m}[2,11,20]$. A negative energy balance is thus the consequence of intake not meeting expenditure, as observed in subjects with comparable energy requirements at sea level.

Water requirement at high altitude theoretically increases due to increased insensible water loss at low ambient water vapour pressure. In practice, however, water loss at altitude is not higher than at sea level $[9,19,20$, 21]. Additional clothing, which reduces cutaneous water efflux, counterbalances the increase in evaporative water loss through the increased breathing in response to the decreased barometric pressure. The opposite of hypohydration, i.e. hyperhydration, sometimes affects a stay at high altitude. Fluid retention is associated with acute mountain sickness (AMS). Subjects who do not show the increase in diuresis that compensates for a reduction of evaporative water loss at altitude develop AMS [21].

The composition of weight loss at altitude is difficult to assess [7]. The generally applied technique for the assessment of body composition during altitude exposure is the skin-fold method. Techniques for the assessment of body composition based on the measurement of the water compartment of the body, like isotope dilution and bio-impedance, are complicated by both fluid shifts and fluid loss at altitude [21], violating the underlying assumption of the method i.e. a fixed hydration of the fat- 
free mass of the body. The skin-fold method is not acceptable when subjects develop peripheral subcutaneous oedema, a common phenomenon during exposure to high altitude [20]. The best option, when conditions allow, is to return to the well-established balance techniques, calculating changes in body composition from the difference between input and output. A relatively new tool in energy and water balance studies is the application of water labelled with ${ }^{2} \mathrm{H}$ and ${ }^{18} \mathrm{O}$ for the assessment of total energy expenditure and total water loss over intervals of $1-3$ weeks.

The present study was designed to measure the effect of hypoxia on energy and water balance during a simulated ascent of Mt. Everest. In this way it was comparable to "Operation Everest II" [13]. The present study included additional measurements of total energy expenditure and total water loss with doubly labelled water, measurement of faecal energy loss as an indicator of nutrient absorption and urinary and faecal loss of nitrogen as a measure of protein balance. The hypotheses were firstly, that hypoxia increases total energy requirement by an increase in total energy expenditure and a reduction of nutrient absorption and secondly, that a decreased barometric pressure increases total water requirement by an increase in insensible water loss.

\section{Methods}

Measurements were performed during progressive hypoxia from 452 to 253 Torr $(4,500$ to $8,848 \mathrm{~m})$ over 31 days, after baseline measurements over 7 days and a 7-day acclimatization at 4,350 m. Baseline and hypoxia measurements were made in a hypobaric chamber in COMEX, Marseille, France. Acclimatization at 4,350 m was achieved, after car and helicopter transport, in a laboratory on Mont Blanc in the French Alps (Observatoire Vallot). The hypobaric chamber consisted of a bedroom, a bathroom and an exercising room with a total volume of $105 \mathrm{~m}^{3}$. Temperature and relative humidity were kept at $18-24{ }^{\circ} \mathrm{C}$ and $30-60 \%$, respectively [12].

Baseline measurements started in nine men, eight subjects for the actual measurements in the hypobaric chamber and one reserve subject. All were selected on the basis of having high-altitude experience and were tested psychologically for their ability to be confined for over a month. They gave their written informed consent to participate in the study. The medical ethics committee of the University Hospital of Marseille approved the protocol. One subject was withdrawn from the study because of pulmonary oedema during the acclimatization at $4,350 \mathrm{~m}$; the reserve subject took his place. Characteristics of the eight experimental subjects were: age $27 \pm 4$ years and body mass index $22.9 \pm 1.5 \mathrm{~kg} / \mathrm{m}^{2}$.

Food and water intake was measured daily in the chamber, in normoxia and hypoxia. The subjects, using table scales to weigh individual food items and a graduated container for volumes of drinks, recorded intake at breakfast and snacks. Records were examined daily with the subject by intercom to clarify and eliminate inconsistencies. Intake during lunch and dinner was recorded by one of the experimenters, who weighed the individually marked items before serving, as well as the left-overs. The macronutrient and water intake was derived from food tables [14].

Total energy expenditure and water loss was measured with doubly labelled water $\left({ }^{2} \mathrm{H}_{2}{ }^{18} \mathrm{O}\right)$ as described before [22]. Observations covered the 31-day interval in the hypobaric chamber during progressive hypoxia from 452 to 253 Torr. Six subjects were given a weighed dose of water with a measured enrichment of approximately 5 atom $\%{ }^{2} \mathrm{H}$ (i.e. $5 \%$ of ${ }^{1} \mathrm{H}$ atoms replaced by ${ }^{2} \mathrm{H}$ ) and 10 atom $\%{ }^{18} \mathrm{O}$ so that isotope levels were increased 150 and
$300 \mathrm{ppm}$ above baseline for ${ }^{2} \mathrm{H}$ and ${ }^{18} \mathrm{O}$, respectively, with an initial dose administered on day 1 of the 31-day interval and a second dose on day 16 . The remaining two subjects collected samples without dosing to allow for corrections due to changes in background abundance. Urine samples for isotope measurement were collected before dose administration (2200-2300 hours), and from the second voiding and the last voiding the next day. Subsequently, every 5th day after dosing urine samples were taken from the second and last voiding. Isotope abundances in urine samples were measured with an isotope-ratio mass spectrometer (Aqua Sira, VG Isogas, Middlewich, UK). $\mathrm{CO}_{2}$ production was converted to energy expenditure by use of an energy equivalent according to the average metabolic fuel quotient calculated from the measured macronutrient composition of the diet and the use of body energy reserves [4]. Water loss was calculated from the deuterium elimination rate corrected for fractionation [5]. Evaporative water loss was calculated as total water loss minus urinary and faecal water loss.

Body composition measurements included body mass, total body water and extracellular water. Body mass was measured daily in all subjects in the morning, after arising and emptying the bladder, in underwear on a scale accurate to $\pm 0.01 \mathrm{~kg}$ (Spider 1, Mettler Toledo, Greifensee, Switzerland). Total body water (TBW) was measured by ${ }^{2} \mathrm{H}$ dilution during the normoxia interval, and at days 2, 17 and 31 of the hypoxia interval in the chamber. Extracellular water (ECW) was measured by $\mathrm{Br}$ dilution during the normoxia interval and at day 31 of the hypoxia interval in the chamber. The control subjects for the measurement of energy expenditure and water loss with doubly labelled water were assessed only on day 31. For the simultaneous measurement of TBW and ECW, subjects consumed a known amount of $\mathrm{NaBr}(60 \mathrm{mg} \mathrm{Br} / \mathrm{l}$ estimated TBW) mixed with approximately 5 atom $\%{ }^{2} \mathrm{H}$ in water so that baseline ${ }^{2} \mathrm{H}$ levels were increased to about $100 \mathrm{ppm}$. Venous blood samples were obtained at 2230 hours, before bromide intake, and at 0800 hours the next morning, within $1 \mathrm{~h}$ before or after the second urine voiding, for the measurement of TBW. Bromide concentration was determined in serum ultrafiltrate using high-performance liquid chromatography and ECW calculated from corrected bromide space as described previously [17]. At days 1 and 16 the ${ }^{2} \mathrm{H}$ was consumed as doubly labelled water (see above).

To determine nutrient absorption and nitrogen balance, subjects collected total faeces and 24-h urine samples for 3 days at normoxia and on days 24-26 of the hypoxia interval in the chamber. Subjects ingested a gelatine capsule containing Brilliant Blue before the first meal and after the last meal of the 3-day intervals to mark the beginning and end of the period of faeces collection as described before [11]. Total faeces and urine production were weighed and homogenized before sampling and storing at $-20^{\circ} \mathrm{C}$. Energy content of the faeces was measured using an adiabatic bomb calorimeter (C-400, IKA Kalorimeter, Janke, Germany). Nitrogen content of faeces and urine was measured with a type CHN-O-rapid analyser (Heraeus, Hanau, Germany).

Results are presented as mean \pm SD unless otherwise stated. Data on energy balance were related to changes in body mass using linear regression and Pearson's correlation coefficients. Intra-individual differences between times were analysed by one-way ANOVA for repeated measures followed by Scheffé's post-hoc test. Data are presented for three intervals of the study, the normoxia interval $(\mathrm{N})$, days 2-16 $(\mathrm{H} 1)$, and days 17-30 $(\mathrm{H} 2)$ during progressive hypoxia in the hypobaric chamber.

\section{Results}

Mean daily energy intake decreased significantly from $\mathrm{N}$ to $\mathrm{H} 1 \quad(-3.2 \pm 2.1 \mathrm{MJ}, P<0.01)$ and from $\mathrm{H} 1$ to $\mathrm{H} 2$ $(-2.1 \pm 0.7 \mathrm{MJ}, P<0.0001$, Table 1$)$. Changes in mean daily water intake between the corresponding intervals were $-0.1 \pm 0.61$ (not significant, n.s.) and $-0.5 \pm 0.31(P<0.05)$, 
Table 1 Energy intake and water intake

a $\mathrm{N}$ normoxia interval, $\mathrm{Hl}$ days 2-16, $H 2$ days $17-30$ during progressive hypoxia in a hypobaric chamber; $* P<0.05$, $* * P<0.01$ and $* * * P<0.0001$ vs. normoxia (ANOVA for repeated measures)

Table 2 Energy expenditure, water loss and urine production

a subjects 1 and 2 were control subjects; $* P<0.05$ vs. normoxia (ANOVA for repeated measures)

\begin{tabular}{|c|c|c|c|c|c|c|}
\hline \multirow[t]{2}{*}{ Subj. No. } & \multicolumn{3}{|c|}{ energy intake (MJ/d) } & \multicolumn{3}{|c|}{ water intake (1/d) } \\
\hline & $\mathrm{Na}^{\mathrm{a}}$ & H1 & $\mathrm{H} 2$ & $\mathrm{~N}$ & H1 & $\mathrm{H} 2$ \\
\hline 1 & $16.0 \pm 1.5$ & $10.1 \pm 2.5$ & $8.8 \pm 2.5$ & $3.4 \pm 0.5$ & $3.0 \pm 0.5$ & $2.9 \pm 0.5$ \\
\hline 2 & $13.6 \pm 1.5$ & $11.2 \pm 2.7$ & $8.8 \pm 1.3$ & $2.4 \pm 0.3$ & $2.6 \pm 0.5$ & $2.1 \pm 0.3$ \\
\hline 3 & $14.9 \pm 1.1$ & $12.6 \pm 1.6$ & $10.5 \pm 2.4$ & $3.3 \pm 1.0$ & $3.3 \pm 0.4$ & $2.9 \pm 0.7$ \\
\hline 4 & $15.3 \pm 1.8$ & $12.9 \pm 1.9$ & $10.3 \pm 3.4$ & $3.0 \pm 0.6$ & $3.3 \pm 0.5$ & $3.0 \pm 0.7$ \\
\hline 5 & $10.6 \pm 1.7$ & $8.9 \pm 1.3$ & $7.7 \pm 1.3$ & $3.6 \pm 0.8$ & $3.3 \pm 0.6$ & $3.0 \pm 0.6$ \\
\hline 7 & $12.5 \pm 1.3$ & $10.7 \pm 2.3$ & $7.4 \pm 3.5$ & $2.9 \pm 0.4$ & $3.0 \pm 0.6$ & $2.3 \pm 0.8$ \\
\hline 8 & $12.5 \pm 1.3$ & $10.4 \pm 1.9$ & $8.6 \pm 2.7$ & $1.8 \pm 0.3$ & $2.3 \pm 0.4$ & $2.0 \pm 0.4$ \\
\hline 9 & $13.3 \pm 1.8$ & $6.2 \pm 2.7$ & $4.5 \pm 2.2$ & $4.7 \pm 0.7$ & $3.3 \pm 0.6$ & $2.3 \pm 0.6$ \\
\hline Mean \pm SD & $13.6 \pm 1.8$ & $10.4 \pm 2.1 * *$ & $8.3 \pm 1.9 * * *$ & $3.1 \pm 0.8$ & $3.0 \pm 0.4$ & $2.6 \pm 0.4 *$ \\
\hline
\end{tabular}

\begin{tabular}{|c|c|c|c|c|c|c|c|}
\hline \multirow[t]{2}{*}{ Subj. No. ${ }^{a}$} & \multicolumn{2}{|c|}{ energy expenditure (MJ/d) } & \multicolumn{2}{|c|}{ water loss $(1 / d)$} & \multicolumn{3}{|c|}{ urine production $(1 / \mathrm{d})$} \\
\hline & H1 & $\mathrm{H} 2$ & H1 & $\mathrm{H} 2$ & $\mathrm{~N}$ & H1 & $\mathrm{H} 2$ \\
\hline 1 & & & & & $2.5 \pm 0.6$ & $1.8 \pm 0.5$ & $1.5 \pm 0.3$ \\
\hline 2 & & & & & $1.8 \pm 0.4$ & $1.5 \pm 0.4$ & $1.2 \pm 0.3$ \\
\hline 3 & 15.1 & 14.8 & 4.4 & 4.6 & $2.3 \pm 0.6$ & $2.4 \pm 0.5$ & $2.3 \pm 0.6$ \\
\hline 4 & 15.1 & 13.8 & 3.9 & 3.7 & $1.6 \pm 0.4$ & $2.0 \pm 0.5$ & $1.7 \pm 0.7$ \\
\hline 5 & 12.0 & 10.5 & 3.7 & 3.7 & $2.0 \pm 0.5$ & $2.2 \pm 0.4$ & $2.0 \pm 0.5$ \\
\hline 7 & 13.6 & 11.6 & 3.6 & 3.0 & $2.1 \pm 0.3$ & $1.9 \pm 0.6$ & $1.5 \pm 0.5$ \\
\hline 8 & 12.2 & 11.0 & 2.6 & 2.3 & $1.0 \pm 0.3$ & $1.2 \pm 0.4$ & $1.0 \pm 0.3$ \\
\hline 9 & 11.6 & 10.9 & 4.0 & 2.8 & $2.6 \pm 0.6$ & $2.5 \pm 0.7$ & $1.5 \pm 0.5$ \\
\hline Mean \pm SD & $13.3 \pm 1.6$ & $12.1 \pm 1.8$ & $3.7 \pm 0.6$ & $3.3 \pm 0.8$ & $2.0 \pm 0.5$ & $1.9 \pm 0.5$ & $1.6 \pm 0.4 *$ \\
\hline
\end{tabular}

respectively. Diet composition was the same throughout intervals $1-3$, i.e. $17 \pm 2 \%$ of energy intake (subsequently termed "energy\%") as protein and a small but insignificant change in the fat energy $\%$ from $36 \pm 5$ to $37 \pm 6$ at the expense of a similar insignificant change in the carbohydrate energy $\%$ from $47 \pm 7$ to $46 \pm 7$.

With respect to expenditure and water balance, the energy content of the faeces increased from $22.3 \pm 0.8 \mathrm{~kJ} / \mathrm{g}$ ash-free dry wt at normoxia to $23.7 \pm 0.7 \mathrm{~kJ} / \mathrm{g}$ ash-free dry wt $(P<0.01)$ on days $24-26$. However, energy digestibility, calculated from gross energy of food intake and total energy loss in the faeces, was the same in the two intervals, $94.5 \pm 2.9 \%$ and $94.2 \pm 1.3 \%$, respectively. Background isotope levels in the control subjects for the measurement of total energy expenditure and water loss showed a linear increase over the 31-day observation interval (Fig. 1). Excess isotope levels in the experimental subjects for the measurement of total energy expenditure and water loss were corrected according to the mean background changes observed in the two control subjects.

Energy expenditure was higher than energy intake in $\mathrm{H} 1(3.0 \pm 1.2 \mathrm{MJ} / \mathrm{day}, P<0.01)$ and in $\mathrm{H} 2(3.9 \pm 1.4 \mathrm{MJ} /$ day, $P<0.001$, Table 2$)$. The mean difference between energy intake and expenditure was $1.0 \pm 0.7 \mathrm{MJ} /$ day larger in $\mathrm{H} 2$ than in $\mathrm{H} 1(P<0.05)$. Total water loss showed a small but insignificant decrease from $\mathrm{H} 1$ to $\mathrm{H} 2$. Urinary water loss was the same in $\mathrm{N}$ and $\mathrm{H} 1$ and decreased by $0.3 \pm 0.31 /$ day in $\mathrm{H} 2(P<0.05)$. Faecal water loss, measured at normoxia and on days 24-26 of the hypoxia interval in the chamber, was not significantly different $(0.09 \pm 0.04$ and
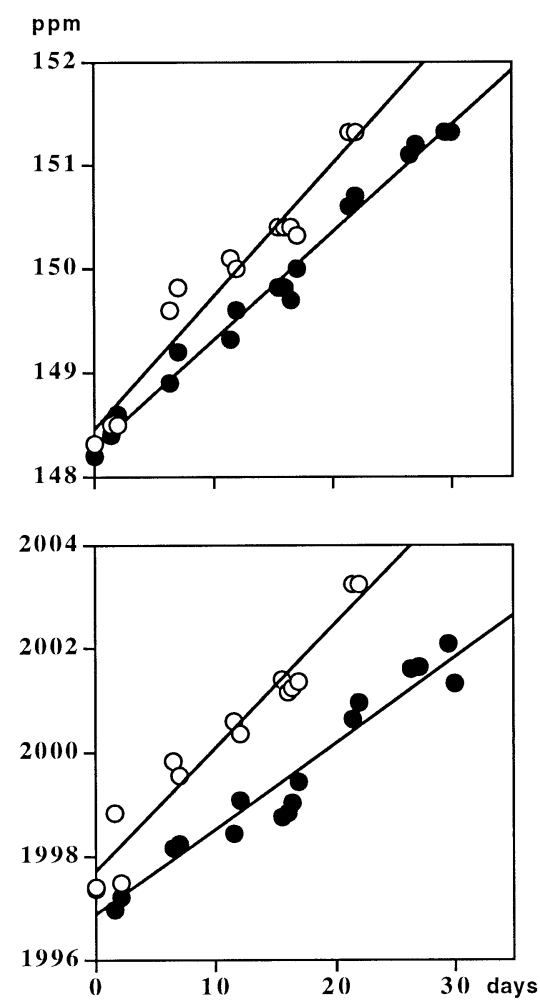

Fig. 1 Levels of ${ }^{2} \mathrm{H}$ (upper panel) and ${ }^{18} \mathrm{O}$ (lower panel) in the two control subjects (open and solid symbols respectively) plotted as a function of the time spent in a hypobaric chamber, with the calculated linear regression lines 


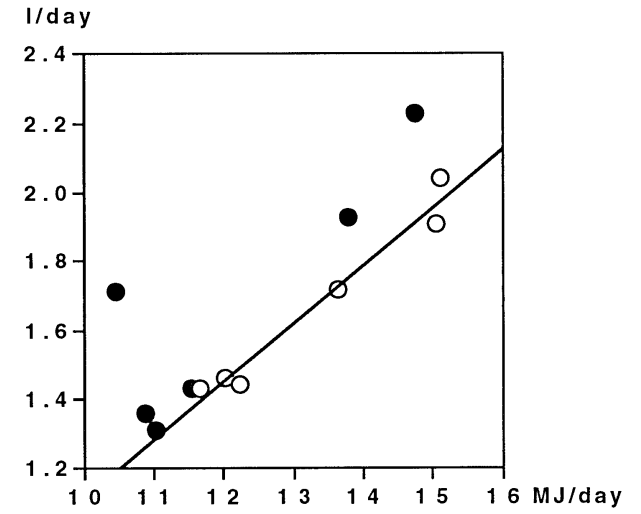

Fig. 2 Evaporative water loss as a function of energy expenditure at 5000-7000 $\mathrm{m}$ (open symbols) and at 7000-8848 m (solid symbols) with the calculated linear regression line at 5000-7000 m: $y=0.173 \cdot x-0.632\left(R^{2}=0.975\right)$, where $y$ is the evaporative water loss in litre/day and $x$ the energy expenditure in megajoule/day

$0.07 \pm 0.31 /$ day, respectively). Evaporative water loss was the same in $\mathrm{N}(1.6 \pm 0.3 \mathrm{l} / \mathrm{day})$ and $\mathrm{H} 1$ (1.6 \pm 0.4 1/day). In $\mathrm{H} 1$, evaporative water loss was closely related to total energy expenditure (Fig. 2, Pearson $R=0.99, P<0.0001$ ). Evaporative water loss adjusted for total energy expenditure was higher in $\mathrm{H} 2$ than in $\mathrm{H} 1$ ( $P<0.05$, Fig. 2$)$.

Body mass changed throughout the experiment. The changes from normoxia to day 2 , over days $2-17$ and over days $17-31$ were $-1.4 \pm 0.8 \quad(P<0.01),-2.5 \pm 1.1$ $(P<0.001)$ and $-1.2 \pm 0.6 \mathrm{~kg}(P<0.01)$, respectively (Table $3)$. The mean change in TBW over the corresponding intervals was $-0.6 \pm 1.0$ (n.s.), $-1.7(P<0.05)$ and $+0.5 \pm 1.51$ (n.s.), respectively. The mean changes in body mass, TBW and ECW from normoxia to the end of the experiment were $-5.2 \pm 1.9 \mathrm{~kg}(P<0.001),-1.7 \pm 1.71$ (n.s.), and $-1.7 \pm 0.71(P<0.01)$, respectively. The rate of change of body mass decreased from a mean of $-0.17 \pm 0.07 \mathrm{~kg} /$ day in interval 2 to $-0.09 \pm 0.05 \mathrm{~kg} /$ day in interval $3(P<0.01)$ while the energy balance changed from $-3.0 \pm 1.2 \mathrm{MJ} /$ day to $-3.9 \pm 1.4 \mathrm{MJ} /$ day $(P<0.05)$. Comparing digestible nitrogen intake with nitrogen output in urine, there was no difference at normoxia $(0.2 \pm 1.8 \mathrm{~g} /$ day $)$, indicating that the subjects were in protein balance. For days 24-26 of the hypoxia interval, urinary nitrogen loss was significantly higher than intake $(4.1 \pm 2.3 \mathrm{~g} / \mathrm{day}, P<0.01)$, indicating a mean body protein loss of $26 \mathrm{~g} /$ day.

\section{Discussion}

Hypoxia induced a negative energy balance, mainly by a reduction of energy intake. The decrease in energy intake from $\mathrm{N}$ to $\mathrm{H} 2$ was $5.3 \mathrm{MJ} /$ day and the decrease in energy expenditure between the corresponding intervals, assuming that energy expenditure at normoxia was equivalent to energy intake, was only $1.5 \mathrm{MJ} /$ day. The negative energy balance of $3.0 \pm 1.2 \mathrm{MJ} /$ day at $5000-7000 \mathrm{~m}$ is comparable to the figure of 2.6-3.5 MJ/day measured during a sojourn on the summit of Mt. Sajama, Bolivia (6,542 m) [20]. The negative energy balance of $3.9 \pm 1.4 \mathrm{MJ} /$ day at $7000-8848 \mathrm{~m}$ is lower than the figure of $5.7 \pm 1.9 \mathrm{MJ} /$ day measured in subjects climbing Mt. Everest [19]. Whereas the subjects on Mt. Sajama spent most of the time reading and underwent some exercise tests, i.e. had a comparable level of physical activity to the subjects in the hypobaric chamber, those on Mt. Everest spent on average $3.5 \mathrm{~h} /$ day climbing, explaining the more negative energy balance compared with the more sedentary subjects at similar altitude in the hypobaric chamber. Indeed, the energy expenditure of the male subjects on Mt. Sajama and in the hypobaric chamber at 5,000-7,000 m was very similar: $13.2 \pm 1.5$ and $13.3 \pm 1.6 \mathrm{MJ} /$ day, respectively. Energy expenditure in the men climbing Mt. Everest and in the hypobaric chamber at 7.000-8,000 m was $14.7 \pm 1.1$ and $12.1 \pm 1.8 \mathrm{MJ} /$ day, respectively, clearly showing the effect of the additional climbing activity on energy expenditure. Energy intake on Mt. Everest and in the hypobaric chamber at 7,000-8,000 $\mathrm{m}$ was very similar, $7.9 \pm 1.6$ and $8.3 \pm 1.9 \mathrm{MJ} /$ day respectively.

Water loss, more specifically evaporative water loss, was not influenced by the ambient pressure reduction. An increase in insensible water loss was largely compensated by a reduction in metabolic rate. Total water loss and urine production in the hypobaric chamber at

Table 3 Body mass, total body water and extracellular water

\begin{tabular}{|c|c|c|c|c|c|c|c|c|c|c|}
\hline \multirow[t]{2}{*}{ Subj. No. ${ }^{a}$} & \multicolumn{4}{|c|}{ body mass $(\mathrm{kg})$} & \multicolumn{4}{|c|}{ total body water (1) } & \multicolumn{2}{|c|}{ extracellular water (1) } \\
\hline & $-10^{\mathrm{b}}$ & 2 & 17 & 31 & 0 & 1 & 17 & 31 & 0 & 31 \\
\hline 1 & 66.5 & 65.6 & 63.9 & 62.3 & & & & 41.3 & & 17.6 \\
\hline 2 & 77.2 & 74.8 & 72.0 & 71.2 & & & & 43.7 & & 16.8 \\
\hline 3 & 80.2 & 77.8 & 76.6 & 75.1 & 51.6 & 50.0 & 50.9 & 49.6 & 20.4 & 18.3 \\
\hline 4 & 82.7 & 81.6 & 78.8 & 78.0 & 52.2 & 52.2 & 49.7 & 50.7 & 21.0 & 18.7 \\
\hline 5 & 72.2 & 71.5 & 68.3 & 67.1 & 45.5 & 44.0 & 42.2 & 41.3 & 17.5 & 15.9 \\
\hline 7 & 70.3 & 69.5 & 67.1 & 66.1 & 46.3 & 47.0 & 44.6 & 45.2 & 18.0 & 17.4 \\
\hline 8 & 65.4 & 64.6 & 62.9 & 62.5 & 41.7 & 41.0 & 39.3 & 42.1 & 16.2 & 14.4 \\
\hline 9 & 80.3 & 78.0 & 73.4 & 70.9 & & 44.3 & 41.9 & 42.5 & & 15.8 \\
\hline Mean \pm SD & $74.3 \pm 6.6$ & $72.9 \pm 6.2 * *$ & $70.4 \pm 5.8 * * *$ & $69.2 \pm 5.7 * * *$ & $47.5 \pm 4.4$ & $46.4 \pm 4.2$ & $44.8 \pm 4.6^{*}$ & $44.6 \pm 3.7$ & $18.6 \pm 2.0$ & $16.9 \pm 1.4 * *$ \\
\hline
\end{tabular}

a Subjects 1 and 2 were control subjects, subject 9 a replacement subject, bdays of progressive hypoxia in a hypobaric chamber; $* P<0.05$, $* * P<0.01$ and $* * * P<0.0001 \mathrm{vs}$. normoxia (ANOVA for repeated measures) 
$7,000-8,000 \mathrm{~m}$ showed a similar tendency for a decrease of $0.4 \mathrm{l} / \mathrm{d}$ and $0.3 \mathrm{l} / \mathrm{d}$, respectively. The evaporative water loss of $1.6 \pm 0.3(\mathrm{H} 1)$ and $1.6 \pm 0.41 /$ day $(\mathrm{H} 2)$, measured in the present study, was slightly higher than the $1.3 \pm$ $0.51 /$ day measured during a stay under comparable sedentary conditions at 4,300 $\mathrm{m}$ [21]. Thus, low ambient pressure under otherwise well-controlled environmental conditions has only a minor effect on evaporative water loss, especially when metabolic rate is reduced, because of a lower level of physical activity. The increase in evaporative water loss adjusted for energy expenditure was probably a consequence of an increase in pulmonary water loss and not of an increase in cutaneous evaporative water loss. The exercise level of the subjects did not increase as also reflected in the figures of the mean energy expenditure of $13.3 \pm 1.6 \mathrm{MJ} / \mathrm{d}$ over $\mathrm{H} 1$ and $12.1 \pm$ $1.8 \mathrm{MJ} / \mathrm{d}$ over H2. Subjects must have had higher pulmonary ventilation at a given level of energy expenditure due to the lower oxygen availability.

Hypoxia-induced body mass loss was initially higher than later on during the experiment while the energy deficit increased. In $\mathrm{H} 1$, subjects showed a decrease in TBW, explaining the high weight loss in the corresponding interval. The average total weight loss over the 31day stay in the hypobaric chamber was $3.6 \mathrm{~kg}$ compared with a total energy deficit of $100.5 \mathrm{MJ}$, i.e. the energy equivalent of $1 \mathrm{~kg}$ weight loss was $28 \mathrm{MJ}$. The energy equivalent is close to the $30 \mathrm{MJ} / \mathrm{kg}$ observed in weightloss studies in which the composition of weight loss is on average $75 \%$ fat mass with an energy equivalent of $38 \mathrm{MJ} / \mathrm{kg}$ and $25 \%$ fat-free mass, being $73 \%$ water and $27 \%$ protein, with an energy equivalent of $4 \mathrm{MJ} / \mathrm{kg}$ [18]. The loss of fat-free mass, i.e. body protein, was confirmed by the negative protein balance of $26 \mathrm{~g} /$ day at the end of the experiment.

The increase of the background isotope levels was unexpected. The ${ }^{2} \mathrm{H}$ enrichment at the start of the 31-day confinement in the hypobaric chamber was similar to the

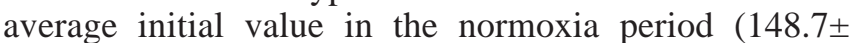
$0.5 \mathrm{ppm}$ ) and within the range of 147-150 ppm observed in subjects consuming lowland drinking water [22]. The mineral water subjects consumed in the hypobaric chamber had an enrichment of $146.9 \pm 0.4 \mathrm{ppm}$ for ${ }^{2} \mathrm{H}$ and $1988.4 \pm 1.4 \mathrm{ppm}$ for ${ }^{18} \mathrm{O}$, close to or lower, but certainly not higher, than the initial background isotope levels in the subjects. The only explanation for the increase in background levels of the two isotopes is re-entry of label in the confined environment of the chamber. The resulting correction of the energy expenditure figures was $-2.4 \pm 0.7 \%$ over interval 1 (days $1-16$ ) and $-4.7 \pm 1.4 \%$ over interval 2 (days 17-30).

The observed food digestibility of $94 \%$ was similar to values measured at sea level $(94 \%$; $[2,24])$ or at $5,050 \mathrm{~m}$ (96\%; [10]). However, the small but significant increase in energy content of the faeces is an indication for malabsorption as observed earlier at 6,542 $\mathrm{m}$ [20]. The magnitude of the change in energy density of the faeces, combined with the technical problem of quantitatively sampling total faeces over the 3-day observation interval as indicated with brilliant blue, resulted in no overall difference in food digestibility between normoxia and the end of the experiment at $8,000-8,848 \mathrm{~m}$. It must also be remembered that energy intake fell by as much as $40 \%$, thus reducing the demand on the intestinal absorptive capacity.

Body composition changes could not be accurately assessed with established methods like isotope dilution. Changes in TBW do not reflect changes in fat-free mass, the basic assumption for many methods for the assessment of body composition including isotope dilution. Based on a fat-free mass hydration of $73 \%$, the change in fat-free mass was $-2.3 \pm 1.8 \mathrm{~kg}$ in $\mathrm{H} 1$ and $+0.8 \pm 2.0 \mathrm{~kg}$ in $\mathrm{H} 2$. The change in fat mass over the corresponding intervals was $-0.4 \pm 1.4 \mathrm{~kg}$ and $-1.9 \pm 1.8 \mathrm{~kg}$, respectively. Calculated changes in body composition based on the measured energy deficit and a composition of weight loss of an average $75 \%$ fat mass, as shown above, were for fatfree mass $-0.6 \pm 0.2$ and $-0.7 \pm 0.2 \mathrm{~kg}$ and for fat mass $-1.1 \pm 0.5$ and $-1.4 \pm 0.5 \mathrm{~kg}$. The body protein loss of $26 \mathrm{~g} /$ day, calculated from urinary nitrogen loss at the end of the experiment at $8,000-8,848 \mathrm{~m}$, confirmed the loss of fat-free mass not reflected in the change of TBW.

Finally, comparing the results of Operation Everest II [13] with the current Operation Everest III, subjects lost $7.4 \pm 2.2$ and $5.2 \pm 1.9 \mathrm{~kg}$, respectively. Measured energy intake over the hypoxia interval was $11.0 \pm 1.2$ and $9.4 \pm 2.0 \mathrm{MJ} / \mathrm{d}$, respectively. Energy expenditure was, respectively, $12.8 \pm 3.1 \mathrm{MJ} / \mathrm{d}$ (estimated) and $12.7 \pm 1.6 \mathrm{MJ} / \mathrm{d}$ (measured). All subjects in Operation Everest II, "lost more weight than would have been expected from comparisons of caloric intake to energy expenditure". Indeed, the expected weight loss based on the balance of estimated energy requirement and measured energy intake, $1.7 \pm 4.3 \mathrm{~kg}$, was much lower than the observed value. One must conclude that the energy requirement was underestimated. However, the measured energy expenditure in Operation Everest III was very similar to the estimated energy expenditure in Operation Everest II. On the other hand, the measured energy intake in Operation Everest II was higher than in Operation Everest III.

Despite the conditions of the current experiment, normal ambient temperature, highly palatable food and mainly sedentary activities, subjects did not maintain energy balance at the simulated high altitude. Initially, at $5,000-6,000 \mathrm{~m}$, they switched to a nibbling eating pattern [23]. Meal size was reduced through a more rapid increase in satiety. An increase in meal frequency partly compensated for the resulting decrease in energy intake. At 7,000 m, the occurrence of AMS symptoms prevented the food intake necessary to meet energy balance requirements. It is concluded that a depressed appetite, combined with a loss of interest in food through mountain sickness, are the main obstacles for maintenance of energy balance at high altitude.

In conclusion, hypoxia induced a negative energy balance, mainly by a reduction of energy intake. The increase in insensible water loss by pressure reduction was compensated by a reduction in metabolic rate. Body 
mass loss was initially higher through a relatively large loss of body water.

Acknowledgements We thank Dr Bernard Gardette for the availability of the hypobaric chamber facilities at the COMEX institute, Marseille, France, and Ing. Loek Wouters for the isotopic analysis of the samples at Maastricht University, The Netherlands.

\section{References}

1. Boyer SJ, Blume FD (1984) Weight loss and changes in body composition at high altitude. J Appl Physiol 57:1580-1585

2. Butterfield GE, Gates J, Sharon S, Brooks GA, Sutton JR, Reeves JT (1992) Increased energy intake minimizes weight loss in men at high altitude. J Appl Physiol 72:1741-1748

3. Consolazio CF, Johnson HL, Krzywicki HJ, Daws TA (1972) Metabolic aspects of acute altitude exposure (4,300 meters) in adequately nourished humans. Am J Clin Nutr 25:23-29

4. Elia M (1990) Converting carbon dioxide production to energy expenditure. In: Prentice AM (ed) The doubly-labelled water method for measuring energy expenditure. NAHRES-4, International Atomic Energy Agency, Vienna, pp 193-211

5. Fjeld CR, Brown KH, Schoeller DA (1988) Validation of the deuterium oxide method for measuring average milk intake in infants. Am J Clin Nutr 48:671-679

6. Fulco CS, Cymerman A, Pimental NA, Young AJ, Maher JT (1985) Anthropometric changes at high altitude. Aviat Space Environ Med 56:220-224

7. Fulco CS, Hoyt RW, Baker-Fulco CJ, Gonzalez J, Cymerman A (1992) Use of bioelectrical impedance to assess body composition changes at high altitude. J Appl Physiol 72:21812187

8. Guilland JC, Klepping J (1985) Nutritional alterations at high altitude in man. Eur J Appl Physiol 54:517-523

9. Hoyt RW, Jones TE, Baker-Fulco CJ, Schoeller DA, Schoene RB, Dchwartz RS, Askew EW, Cymerman A (1994) Doubly labeled water measurement of human energy expenditure during exercise at high altitude. Am J Physiol 266:R966-R971

10. Kayser B (1992) Nutrition at high altitude. Int J Sports Med 13 (Suppl 1):129-131

11. Kayser B, Acheson K, Decombaz J, Fern E, Cerretelli P (1992) Protein absorption and energy digestibility at high altitude. J Appl Physiol 73:2425-2431
12. Richalet J-P, Robach P, Jarrot S, Schneider J-C, Mason NP, Cauchy E, Herry J-P, Bienvenu A, Gardette B, Gortan C (1999) Operation Everest III (Comex '97): effects of prolonged and progressive hypoxia on humans during a simulated ascent to $8,848 \mathrm{~m}$ in a hypobaric chamber. In: Roach RC, Wagner PD, Hackett PH (eds) Hypoxia: into the next millennium. Kluwer Academic/Plenum, New York

13. Rose MS, Houston CS, Fulco CS, Coates G, Sutton JR, Cymerman A (1988) Operation Everest II: nutrition and body composition. J Appl Physiol 65:2545-2551

14. Stichting Nederlands Voedingsstoffenbestand (1996) Dutch nutrient data base 1996. Voorlichtingsbureau voor de voeding. The Hague, The Netherlands

15. Stock MJ, Norgan NG, Ferro-Luzzi A, Evans E (1978) Effect of altitude on dietary-induced thermogenesis at rest and during light exercise in man. J Appl Physiol 45:345-349

16. Surks MI, Chinn KSK, Matoush LO (1966) Alterations in body composition in man after acute exposure to high altitude. J Appl Physiol 21:1741-1746

17. Van Marken Lichtenbelt WD, Westerterp KR, Wouters L, Luijendijk SCM (1994) Validation of bioelectrical-impedance measurements as a method to estimate body-water compartments. Am J Clin Nutr 60:159-166

18. Westerterp KR, Donkers J, Fredrix EWHM, Boekhoudt P (1995) Energy intake, physical activity and body weight; a simulation model. Br J Nutr 73:337-347

19. Westerterp KR, Kayser B, Brouns F, Herry JP, Saris WHM (1992) Energy expenditure climbing Mt. Everest. J Appl Physiol 73:1815-1819

20. Westerterp KR, Kayser B, Wouters L, Le Trong JL, Richalet JP (1994) Energy balance at high altitude: 6542 m. J Appl Physiol 77:862-86

21. Westerterp KR, Robach P, Wouters L, Richalet JP (1996) Water balance and acute mountain sickness before and after arrival at high altitude: 4,350 m. J Appl Physiol 80:1968-1972

22. Westerterp KR, Wouters L, Van Marken Lichtenbelt WD (1995) The Maastricht protocol for the measurement of body composition and energy expenditure with labeled water. Obes Res 3 (Suppl 1):49-57

23. Westerterp-Plantenga MS, Westerterp KR, Rubbens M, Verwegen CRT, Richalet J-P, Gardette B (1999) Appetite at "high altitude" [Operation Everest III (Comex-'97)]: a simulated ascent of Mount Everest. J Appl Physiol 87:391-399

24. Widdowson EM (1955) Assessment of the energy value of human foods. Proc Nutr Soc 14:142-154 